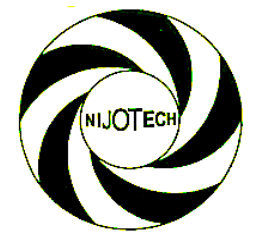

Nigerian Journal of Technology (NIJOTECH)

Vol. 35, No. 2, April 2016, pp. 278 - 289

Copyright@ Faculty of Engineering, University of Nigeria, Nsukka,

Print ISSN: 0331-8443, Electronic ISSN: 2467-8821

www.nijotech.com

http://dx.doi.org/10.4314/njt.v35i2.7

\title{
SENSITIVITY ANALYSIS ON FLEXIBLE ROAD PAVEMENT LIFE CYCLE COST MODEL
}

\author{
H. A. P. Audu ${ }^{1}$, E. E. Oghorodje ${ }^{2}$ and D. E. Oviri ${ }^{3}$ \\ 1 Dept. of Civil Engineering, FaCulty of EngineERing, University of Benin, Benin City, Edo State, NigERIA. \\ 2 Department of HighWAY EngineEring, MinisTry of Works, ASABA, Delta State, NiGERIA. \\ 3 Works Department, Uvwie Local Government Council, EFfurun, Delta State, NIGERIA. \\ E-mailaddresses:1henrypauduus@yahoo.com,2eoghorodje@gmail.com;3engrdicta@hotmail.com
}

\begin{abstract}
Sensitivity analysis is a tool used in the assessment of a model's performance. This study examined the application of sensitivity analysis on a developed flexible pavement life cycle cost model using varying discount rate. The study area is Effurun, Uvwie Local Government Area of Delta State of Nigeria. In order to determine one of the vital geotechnical engineering properties (i.e. California Bearing Ratio) of the soil samples required for this study, soil samples were taken from the subgrade of the study area using the disturbed sampling method. The laboratory test was carried out at geotechnical laboratory in Warri and in accordance with AASTHO 1993 to determine the subgrade strength. Existing data such as maintenance records, vehicular traffic counts, material costs, discount rate and pavement design data were sourced from the Delta State Ministry of Works, Effurun. These acquired data and CBR results of 5\% and 6\% were used for the design of three competing flexible pavement systems and Bill of Engineering Measurements obtained. These were used for the evaluation of the Life-Cycle Costs (LCCS) using present worth cost (PWC) method; varying discount rates in MS Excel spread sheets for a design life of 20 years. Regression modeling of the three scenarios was done with sensitivity analysis carried out on the developed model. The project age was used as its independent variable, while discount rate is a secondary independent variable varied by $\pm 4 \%, \pm 8 \%$ and $\pm 12 \%$ of the initial discount rate of $5.4 \%$ applied with the accuracy of $95 \%$. The coefficient of determination ( $\left.R^{2}\right)$ for the Hot Rolled Asphalt (HRA), Interlocking Concrete Pavement Block (ICPB) and Do-nothing models are 0.97, 0.95 and 0.99 respectively indicating a robustness of the developed models. The graphs produced from the sensitivity analysis indicate a decrease in life cycle cost with increasing interest rate for the alternatives. These results are vital for the economic evaluation of flexible pavement and transportation systems.
\end{abstract}

Keywords: Sensitivity analysis, flexible road pavement, life cycle cost model and Present worth Cost.

\section{INTRODUCTION}

The demand for transport infrastructure systems is enormous due to the ever-growing population, industrialization and urbanization growth in developing countries. The cost of meeting this huge infrastructural demand places so much pressure on government's limited resources [1] and [2].

During the life cycle of an infrastructure so many uncertainties and predictions are involved. These include, design assumptions, construction methodology choice, maintenance strategy and soil testing and results analysis. Road infrastructure like in every other sector requires huge funding and maintenance. A systematic monetary valuing process is required to justify the amount needed for its planning, design, procurement and pavement maintenance in road infrastructure [3].

The highway engineer can increase confidence in the decision made in transportation infrastructure delivery, in the midst of so much risk in the project delivery, is by carrying out a sensitivity analysis on the life cycle cost model used as the decision support tool [4]; [5]; [6] and [7]. The two most commonly used methods of assessing and managing the risk and uncertainties are probabilistic analysis and sensitivity analysis. The probabilistic approach combines 
probability descriptions of analysis inputs to generate the entire range of outcomes as well as the likelihood of occurrence. Probabilistic analysis represents uncertainties more realistically than does a sensitivity analysis. Sensitivity analysis assigns the same weighting to all extreme or mean values, whereas probabilistic analysis assigns the lowest probability to extreme values [8]. In this paper, the sensitivity analysis is examined with a view to cross checking the simple deterministic life cycle cost model earlier developed by the authors.

Sensitivity analysis is a technique used to determine the influence of major data variable resulting from input assumptions, projections and estimates on life cycle cost analysis results [9] and [10]. Major input values are varied while all other input values remain constant and the amount of change in results is noted [11] and [1]. Sensitivity analysis is a necessary tool which helps in figuring out which of the design decision variables in a model is mostly influential or has more relative significance on a decision made. The use of sensitivity analysis for the investigation of the life cycle cost model in pavement infrastructure is relevant following the likely errors and inconsistencies in estimation or prediction costs and financial data, traffic loading prediction, pavement and geometrical design variables.

Generally, when a project is evaluated deterministically over its lifecycle, the planning, design, delivery, maintenance, asset management strategies are generated using expert opinions and experiences based on practice and project history within the planning agency. However, in the life cycle cost studies in flexible pavement delivery, it is important that planned rehabilitation and timing strategy, in-situ material and subsoil tests and traffic loading assessments necessary for the geometrical and pavement design of the traffic corridor be considered. [12] posited that in real life most infrastructure projects can undergo a number of rehabilitation activities at any time during the analysis period and that some of the established design processes entail certain assumptions.

The objectives of the study are to carry out the sensitivity analysis on the life cycle analysis model developed for the road pavement in the study area as well as determine the effect of the sensitivity analysis of the three competing pavement alternatives.

\section{LITERATURE REVIEW}

The initial framework for the life cycle cost model was developed in the late 90s. Transportation infrastructure life cycle cost model are based on statistically derived cost estimating relationships (CER) and various methodology used to predict the cost of such schemes or infrastructures [10]. There are known to consist of specific previous construction, fiscal and cost database, material attributes and maintenance estimates and prediction. These are either estimated from an engineering planning and design exercises or simply predicted to approximate the real world. However the experience and professional judgment of the developer of the model is paramount in the confidence and quality level of the resulting LCC model.

Life cycle cost can be optimized for the great gains of best transportation infrastructure investments in developing countries. Transportation models already exist in the form of the four basic steps of transportation viz: trip generation, distribution, assignment and modal choice or tour based or activity based time. These models include the Delta, PECAS, UPLAN, DEPHI and Urban Sim. From literature, these models are not holistically available for the highway engineer or transportation economics in the developing countries because these models are organizations and specific projects needs based.

Life-cycle cost is suggested as a parameter when selecting road designs or evaluating bids [13] and [14]. Unfortunately, life-cycle cost analyses are still of less importance in bid evaluations due to difficulties related to the absence of reliable data and methods for calculating life-cycle costs for road projects [6].

Lack of maintenance culture and investment related data is attributable to the fact that most road authorities do not have proper methods for systematic data collection and banking regarding the planning, design, construction and maintenance of infrastructure. Absence of reliable life-cycle cost methods is also due to the lack of accurate road deterioration models as well as models for calculating user's or societal costs. Current deterioration models are based on experience and empirical models [4]; such models can give acceptable results, if only the historical circumstances are similar to future circumstances. However, such circumstances seldom exists for road construction due to, among other things, traffic development, use of heavier vehicles and new types of tires and transport systems upgrade and development. Sensitivity and risk analysis are 
useful in understanding and handling these envisaged uncertainties to ensure a high confidence level of the results obtainable from the proposed LCC model.

In another Life-Cycle Cost study on the estimation of the environmental impacts of fuel fired cogeneration plants reported in the proceedings of 2000 International Joint Power Generation Conference, [15] opined that any of the variables can be estimated using the Life-Cycle Cost concept for decision making. It is in the process of the sensitivity analysis that the most critical cost variables in the infrastructure life cycle in the life cycle can be detected and effectively managed.

Previous related studies on sensitivity analysis on project evaluation models include the works of [1624] in a developing country. In the work of [17] input parameters or assumptions used in the model formulation were ranked according to their influence, the baseline valuation criteria or model using the Tornado diagram. This approach is probabilistic and cumbersome leading to more presumptions and thus more risk in the decision making process. In related work, [16] focused on differential importance measure (DIM) mathematical frame work. [25] in their work provided a detailed zone users costs and introduced a probabilistic approach to account for uncertainties.

However, most of these works already done in transportation infrastructure delivery are either complex studies or specific-need based for environments in developed countries design for very heavy annual daily traffic (ADT). In developing countries where the unavailability of project cost evaluation cost models, absence of users cost and road maintenance data bank, poor pavement design and maintenance infrastructure and resources and technological information gaps exists. Our studies is a deterministic one where a case study area typical of the Niger Delta region is examined in an urban environment with a low design speed and traffic annual daily volume(ADT).

This work tests the flexible pavement cost model with varying interest rate for an already procured, developed and completed urban road infrastructure corridor using Microsoft Excel and SPSS v20 software [24]. It examines how the variation in interest rates affects the present worth life cycle cost for the competing pavement alternatives in Million Naira/Kilometer.

\section{MODEL FORMULATION}

The present worth method of economic evaluation involves the conversion of all the present and future estimated expenses to a base of today's costs using an appropriate interest rate. The total of the computed present value costs are then compared with one another. The present worth of costs method is directly comparable to the equivalent uniform annual cost method for comparable benefits [26]. In this study, a limitation to the present worth cost method is made for clarity using tropical information from field practice, experience and agency costs. The general expression for the Present Worth Cost of a transportation infrastructural project is given by [27]. $P W C=$ Initial $\cos t+\sum_{K-1}^{N} \operatorname{Re} h a b \cos t \frac{1}{\left[(1+i)^{n k}\right]}$

In (1), $\mathrm{i}$ is the interest rate, $n$ is the year of expenditure or age of infrastructure, $\frac{1}{\left[(1+i)^{n k}\right]}=$ present value factor. Following equation (1) above, a linear relation for the life cycle cost (LCC) for the competing pavement alternatives are represented in a linear relationship as shown in the model form below.

$Y=b+m x+e$

Here, $Y$ is the Dependent variable, deterministic Present worth Cost of alternative Pavement or infrastructure or scheme in Million Naira, $b$ is the Independent variable, regression constant or vertical intercept on the cost axis Agency's (Pre-construction+ Initial Construction) in Million Naira, $m$ is the Regression coefficient or slope of trend line relating the cost and the entire project life (a function of the annual expenditure, salvage value, analysis period, discount rate), $x$ is the Independent variable, particular period or year of interest of projection of the present worth cost in year, and $\mathrm{e}$ is the Independent variable, other costs (such as socioeconomic and political cost element and error term due to uncertainty in data analyses.

\section{METHODOLOGY}

The soil samples were taken from the subgrade of the study area using the disturbed sampling method and were transported to the Geotechnical engineering laboratory in Warri for California Bearing Ratio (CBR) laboratory tests on the samples. The CBR test, which is a vital geotechnical engineering properties required for the design of flexible pavement, was carried out in accordance with the American Association of State highway and Transportation Officials (AASHTO) in 
order to determine the in-situ subgrade strength as required for flexible pavement design [28]. The study was carried out using existing input data such as: maintenance records, vehicular traffic counts, material and market survey reports, discount rate, the reports of route investigation, geometric and pavement design and cost data sourced from the Delta State Ministry of Works, Effurun, Nigeria. The acquired existing data and the soil subgrade CBR test result of $4 \%$ were used for the design of three competing flexible pavement systems; Hot Rolled Asphalt (HRA), Interlocking Concrete Block Pavement (ICBP) and a third; Donothing scenario pavement surface courses.

The input data and variables obtained from the Ministry of Works, Effurun, Delta State, Nigeria also includes maintenance records, average commercial vehicle counts per day of 400 of a single carriageway from which the future traffic Estimated Standard Axles Loading (ESAL) of 5.27x $10^{6}$ was calculated. A factor of safety of 1.2 was allowed for overloading and constant exposure of pavement to seasonal over flooding due to the flatness of the terrain for a period of 20years and $4 \%$ growth rate. In the location of study, a design speed of $60 \mathrm{~km} / \mathrm{hr}$, applicable to urban roads was used in the geometric design for single carriage way.

From the alternative sectional full depth designed, the Bill of Engineering Measurements and Evaluation (BEME) was developed for the design alternatives. These were later used for the evaluation of the LifeCycle Costs (LCCs) using present worth cost (PWC) method and varying discount rates in MS Excel spread sheets for a design life of 20 years. For the third alternative, no surfacing course was provided (DoNothing). This implies that, sub-base and base course are common to all the three alternatives.

Regression modeling with computer software's (SPSS and MS Excel) package for all three scenarios was done. The sensitivity analysis was carried out on the developed model. The project age was used as its independent variable, while discount rate is a secondary independent variable varied by $\pm 4 \%, \pm 8 \%$ and $\pm 12 \%$ of the initial discount rate of $5.4 \%$ applied. This was done on the MS Excel spreadsheets and SPSS Version 20 with the accuracy of $95 \%$. The variations in the outcomes of the life cycle cost with the varying interest are presented in the sensitivity analysis graphs.

\section{RESULTS AND DISCUSSION}

\subsection{Results}

Fig. 1 presents the typical full depth cross sections alternatives of the urban road. Table 1 is the summary of Bill of Engineering Measurements and Evaluation of the competing pavement alternatives.

Tables 2-4 show the summary of the statistical output for the three (3) competing pavement alternatives models. The combined life-cycle costs (LLCs) and the pavement age plot for the three competing flexible pavement alternatives at $6.2 \%$ interest rate is shown in Fig. 2.

Figs. 3-8 present the Life-Cycle Costs versus Pavement age and Normal probability percentile plots for each of the competing pavement alternatives. Fig. 9 presents the Life-Cycle Costs versus Interest rate sensitivity graph for the models developed.

Table 1: Summary of Bill of Engineering Measurements and Evaluation for the competing alternatives (Adapted from Proposed Delta State Ministry of Works BEME, 2011)

\begin{tabular}{|c|c|c|c|c|c|}
\hline Item No. & Description & Unit & Qty & Rate $(\mathbf{N})$ & Amount (N) \\
\hline \multicolumn{6}{|c|}{ BILL NO. 4: PAVEMENT AND SURFACING (HRA) } \\
\hline 4.01 & $\begin{array}{l}\text { Provide and lay prime coat of } \mathrm{MC} 0 / \mathrm{MC} 1 \text { cut back bitumen at a } \\
\text { rate of } 0.9 \text { litres/sq.m including sharp sand or quarry dust } \\
\text { blinding }\end{array}$ & $\mathrm{m}^{2}$ & 11,400 & 250 & $2,850,000.00$ \\
\hline 4.02 & $\begin{array}{l}\text { Provide and apply butiminous emulsion tack coat on the entire } \\
\text { carriage way }\end{array}$ & $\mathrm{m}^{2}$ & 11,400 & 220 & $2,508,000.00$ \\
\hline 4.03 & $\begin{array}{l}\text { Provide and lay } 50 \mathrm{~mm} \text { compacted thickness of HRA concrete } \\
\text { binder course of } 5 \% \text { bitumen content. }\end{array}$ & $\mathrm{m}^{2}$ & 11,400 & 3,000 & $34,200,000.00$ \\
\hline 4.04 & $\begin{array}{l}\text { Provide and apply butiminous emulsion tack coat on the entire } \\
\text { carriage way }\end{array}$ & $\mathrm{m}^{2}$ & 11,400 & 220 & $2,508,000.00$ \\
\hline 4.05 & $\begin{array}{l}\text { Provide and lay } 40 \mathrm{~mm} \text { compacted thickness of HRA wearing } \\
\text { course of } 6 \% \text { bitumen content. }\end{array}$ & $\mathrm{m}^{2}$ & 11,400 & 2,700 & $30,780,000.00$ \\
\hline & Total Bill No. 4 Carried to Summary & & & & $72,846,000.00$ \\
\hline \multicolumn{6}{|c|}{ BILL NO. 4: PAVEMENT \& SURFACING (ICPB) } \\
\hline 4.01 & Provide and lay damp proof and appropriate filter membrane & $\mathrm{m}^{2}$ & 11,400 & 200 & $2,280,000.00$ \\
\hline
\end{tabular}




\begin{tabular}{|c|c|c|c|c|c|}
\hline Item No. & Description & Unit & Qty & Rate $(\mathbf{N})$ & Amount (N) \\
\hline 4.02 & $\begin{array}{l}\text { Provide and lay } 75 \mathrm{~mm} \text { thick approved interlocking stones } \\
\text { compacted sharp bedding on the entire carriage way including } \\
\text { kerbs }\end{array}$ & $\mathrm{m}^{2}$ & 11,400 & 4,000 & $45,600,000.00$ \\
\hline & Total Bill No. 4 Carried to Summary & & & & $47,880,000.00$ \\
\hline \multicolumn{6}{|c|}{ BILL NO. 4: PAVEMENT AND SURFACING (DO-NOTHING) } \\
\hline 4.01 & $\begin{array}{l}\text { Provide and lay prime coat of } \mathrm{MC} 0 / \mathrm{MC} 1 \text { cut back bitumen at a } \\
\text { rate of } 0.9 \text { litres/sq.m including sharp sand or quarry dust } \\
\text { blinding }\end{array}$ & $\mathrm{m}^{2}$ & 11,400 & & - \\
\hline 4.02 & $\begin{array}{l}\text { Provide and apply butiminous emulsion tack coat on the entire } \\
\text { carriage way }\end{array}$ & $\mathrm{m}^{2}$ & 11,400 & & - \\
\hline 4.03 & $\begin{array}{l}\text { Provide and lay } 50 \mathrm{~mm} \text { compacted thickness of HRA concrete } \\
\text { binder course of } 5 \% \text { bitumen content. }\end{array}$ & $\mathrm{m}^{2}$ & 11,400 & & - \\
\hline 4.04 & $\begin{array}{l}\text { Provide and apply butiminous emulsion tack coat on the entire } \\
\text { carriage way }\end{array}$ & $\mathrm{m}^{2}$ & 11,400 & & - \\
\hline \multirow[t]{2}{*}{4.05} & $\begin{array}{l}\text { Provide and lay } 40 \mathrm{~mm} \text { compacted thickness of HRA wearing } \\
\text { course of } 6 \% \text { bitumen content. }\end{array}$ & $\mathrm{m}^{2}$ & 11,400 & & - \\
\hline & Total Bill No. 4 Carried to Summary & & & & $\begin{array}{l}\text { Nil cost for } \\
\text { Surfacing }\end{array}$ \\
\hline
\end{tabular}

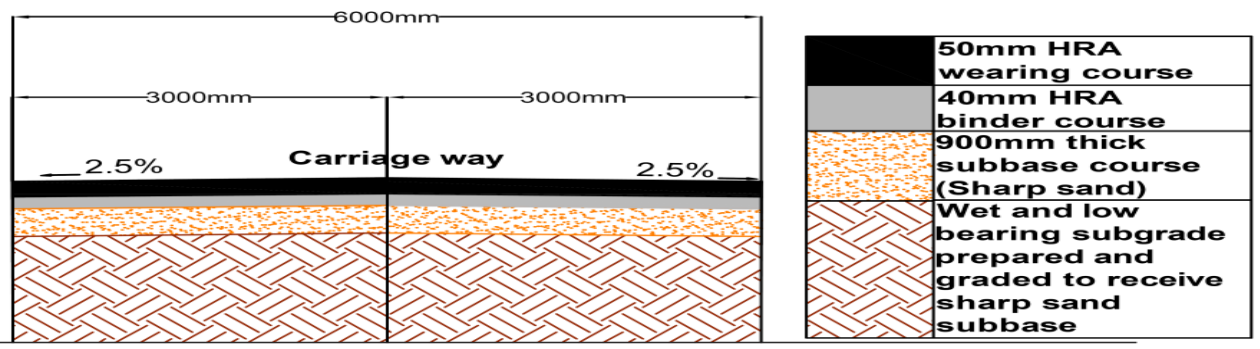

Hot Roll Asphalt (HRA)

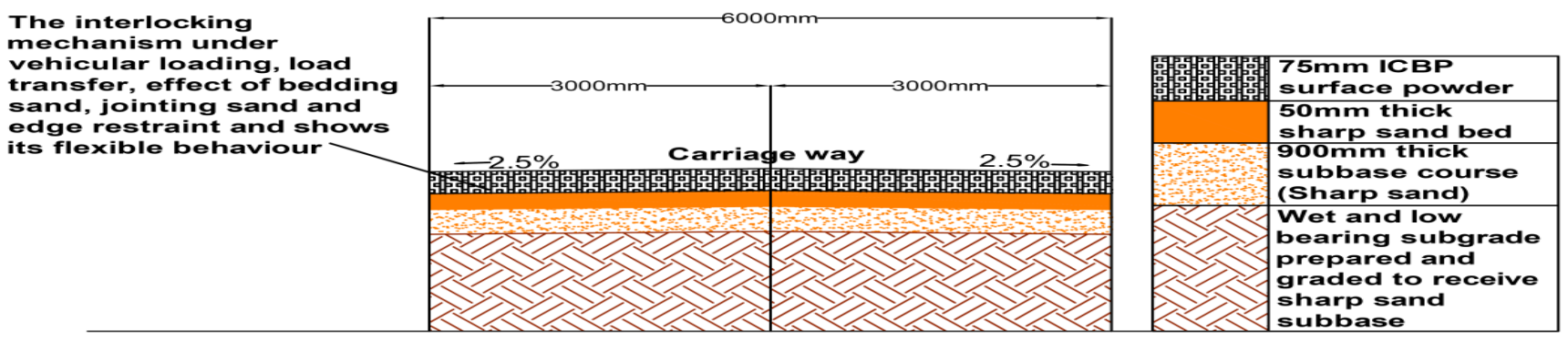

Interlocking Concrete Block Pavement (ICBP)

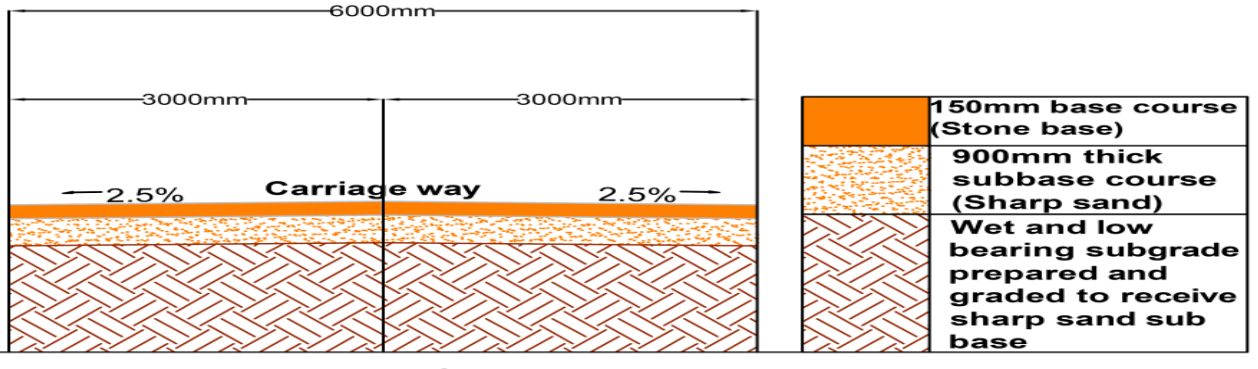

Do-nothing Scenario

Fig. 1: Typical cross section of the road used for this study 


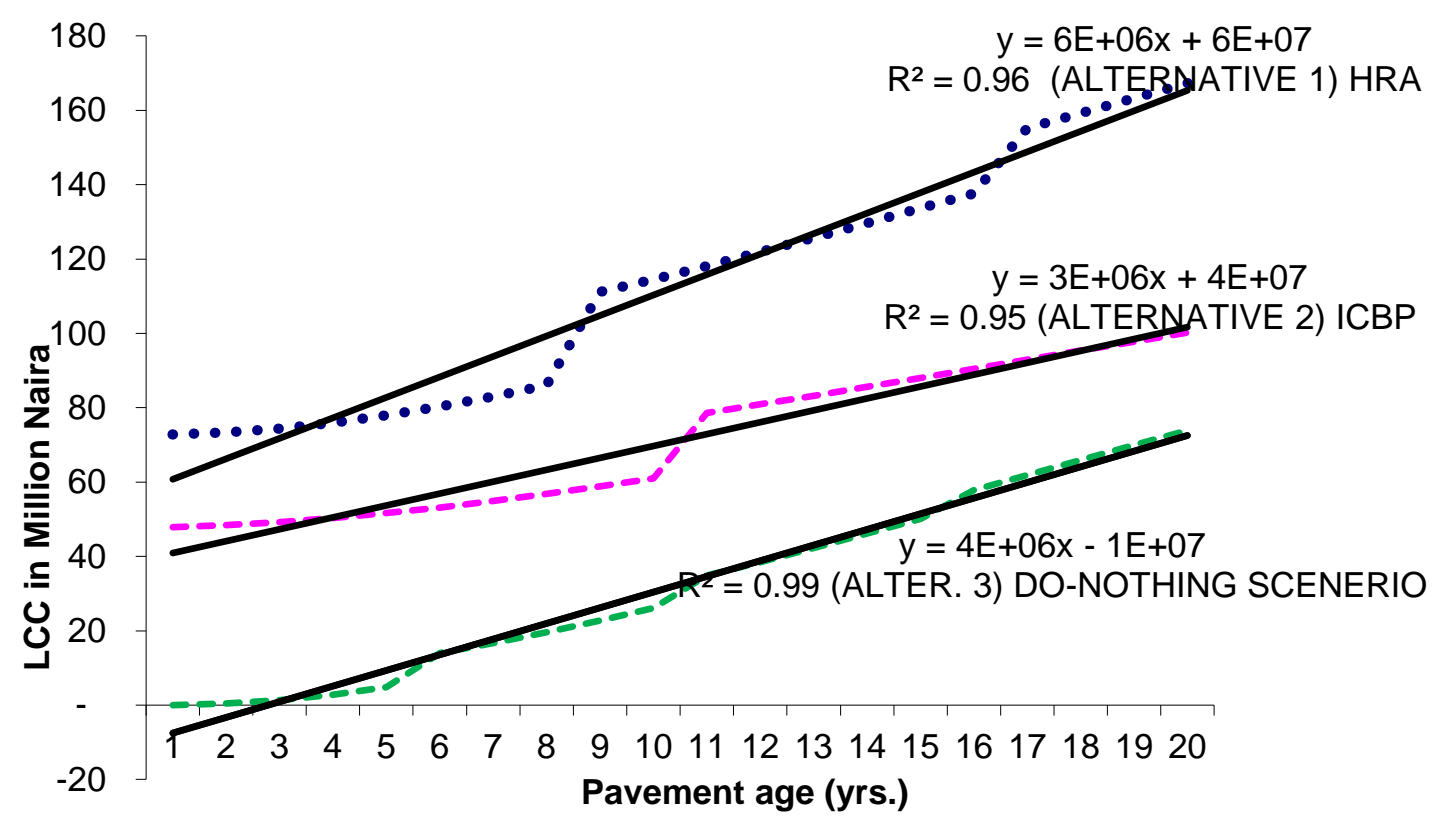

Fig. 2: Combined LCC versus Pavement age plots for the three competing flexible pavement alternatives at $6.2 \%$ interest rate. (The bold lines represent the cost model for the alternatives considered).

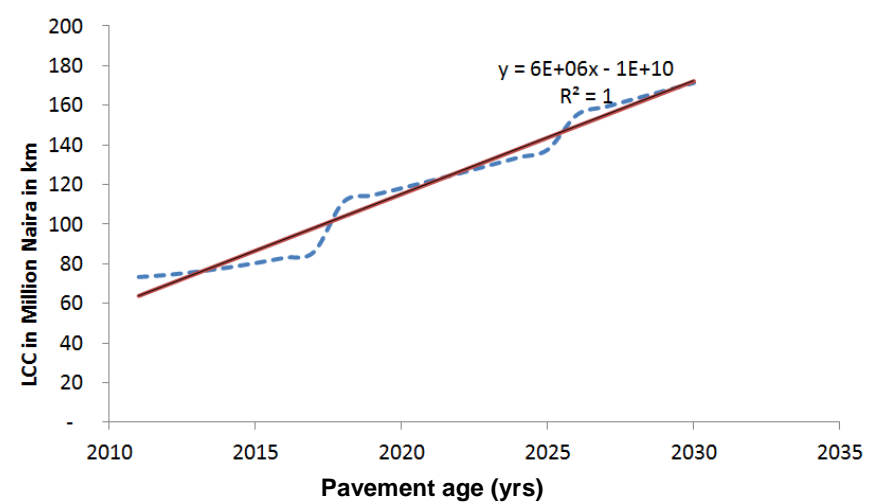

Fig. 3: Life Cycle Cost vs Pavement age plot for HRA model

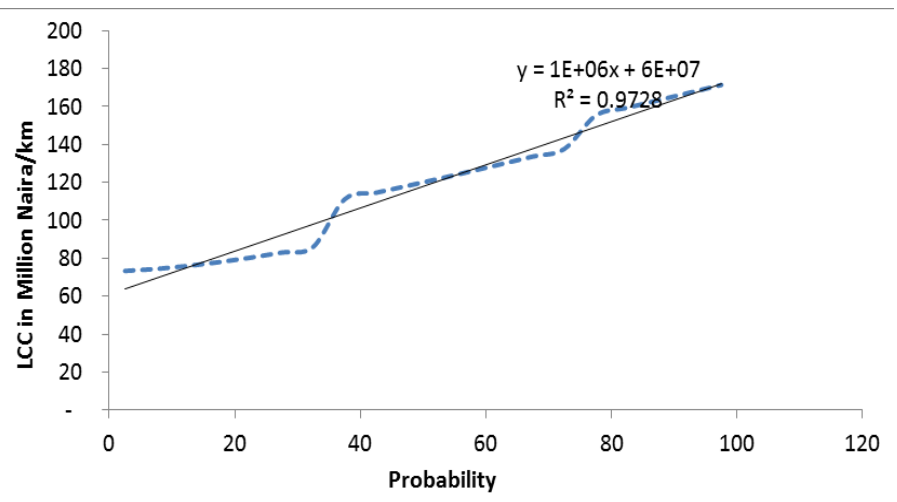

Fig. 4: Life Cycle Cost vs Probability plot for HRA model

Table 2: Summary of the output of Life-Cycle Cost for HRA model

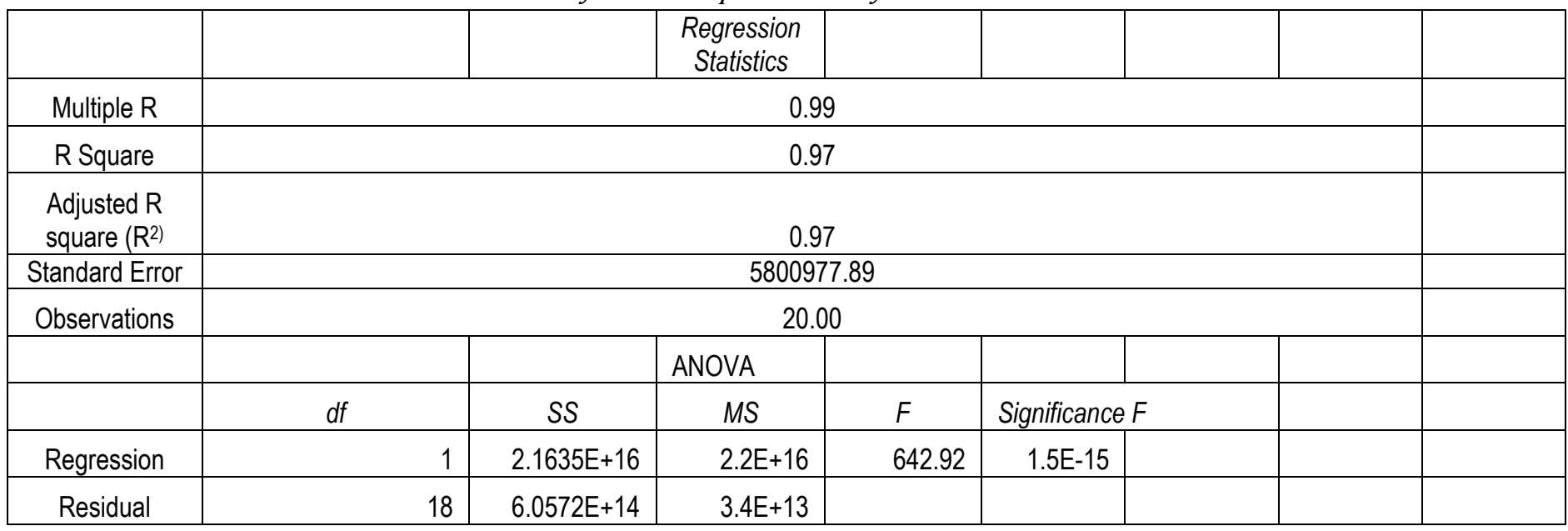




\begin{tabular}{|c|c|c|c|c|c|c|c|c|}
\hline Total & 19 & $2.2241 \mathrm{E}+16$ & & & & & & \\
\hline & Coefficients & Standard Error & t Stat & $P$-value & $\begin{array}{c}\text { Lower } \\
95 \%\end{array}$ & Upper 95\% & $\begin{array}{l}\text { Lower } \\
95.0 \%\end{array}$ & $\begin{array}{l}\text { Upper } \\
95.0 \%\end{array}$ \\
\hline Intercept & -11406645573 & 454517920 & -25.096 & 1.9E-15 & $-1 \mathrm{E}+10$ & $-1 E+10$ & $-1 \mathrm{E}+10$ & $-1 \mathrm{E}+10$ \\
\hline \multirow[t]{2}{*}{2010} & 5703860.325 & 224952.274 & 25.3559 & $1.5 \mathrm{E}-15$ & 5231253 & 6176468 & 5231253 & 6176468 \\
\hline & & \multicolumn{2}{|l|}{ Residual output } & & \multicolumn{2}{|c|}{ Probility output } & & \\
\hline Observation & Predicted 72846000 & \multicolumn{2}{|c|}{ Residuals } & Percentile & \multicolumn{4}{|c|}{$72,846,000$} \\
\hline 1 & $63,817,541.20$ & \multicolumn{2}{|c|}{9528458.798} & 2.5 & \multicolumn{4}{|c|}{$73,346,000$} \\
\hline 2 & $69,521,401.53$ & \multicolumn{2}{|c|}{4890115.373} & 7.5 & \multicolumn{4}{|c|}{$74,411,517$} \\
\hline 3 & $75,225,261.85$ & \multicolumn{2}{|c|}{749554.4887} & 12.5 & \multicolumn{4}{|c|}{$75,974,816$} \\
\hline 4 & $80,929,122.18$ & \multicolumn{2}{|c|}{-2954976.928} & 17.5 & \multicolumn{4}{|c|}{$77,974,145$} \\
\hline 5 & $86,632,982.50$ & \multicolumn{2}{|c|}{-6279718.191} & 22.5 & \multicolumn{4}{|c|}{$80,353,264$} \\
\hline 6 & $92,336,842.83$ & \multicolumn{2}{|c|}{-9275828.17} & 27.5 & \multicolumn{4}{|c|}{$83,061,015$} \\
\hline 7 & $98,040,703.15$ & \multicolumn{2}{|c|}{-11989786.81} & 32.5 & \multicolumn{4}{|c|}{$86,050,916$} \\
\hline 8 & $103,744,563.48$ & \multicolumn{2}{|c|}{7384454.173} & 37.5 & \multicolumn{4}{|c|}{$111,129,018$} \\
\hline 9 & $109,448,423.80$ & \multicolumn{2}{|c|}{5112241.776} & 42.5 & \multicolumn{4}{|c|}{$114,560,666$} \\
\hline 10 & $115,152,284.13$ & \multicolumn{2}{|c|}{3007230.368} & 47.5 & \multicolumn{4}{|c|}{$118,159,514$} \\
\hline 11 & $120,856,144.45$ & \multicolumn{2}{|c|}{1038201.431} & 52.5 & \multicolumn{4}{|c|}{$121,894,346$} \\
\hline 12 & $126,560,004.78$ & \multicolumn{2}{|c|}{-822988.3203} & 57.5 & \multicolumn{4}{|c|}{$125,737,016$} \\
\hline 13 & $132,263,865.10$ & \multicolumn{2}{|c|}{-2601659.602} & 62.5 & \multicolumn{4}{|c|}{$129,662,206$} \\
\hline 14 & $137,967,725.43$ & \multicolumn{2}{|c|}{-4320544.208} & 67.5 & & 133,6 & 181 & \\
\hline 15 & $143,671,585.75$ & -600000 & 997 & 72.5 & & 137,6 & 585 & \\
\hline 16 & $149,375,446.08$ & 584446 & & 77.5 & & 155,2 & 910 & \\
\hline 17 & $155,079,306.40$ & 419129 & 079 & 82.5 & & 159,2 & 601 & \\
\hline 18 & $160,783,166.73$ & 252879 & 336 & 87.5 & & 163,3 & 961 & \\
\hline 19 & $166,487,027.05$ & 844245 & 087 & 92.5 & & 167,3 & 272 & \\
\hline 20 & $172,190,887.38$ & -87355 & 825 & 97.5 & & 171,3 & 336 & \\
\hline
\end{tabular}

Table 3: Summary of the output of the Life Cycle Cost for Interlocking Concrete Block

\begin{tabular}{|c|c|c|c|c|c|c|c|c|}
\hline & & & Regression Statistics & & & & & \\
\hline Multiple R & \multicolumn{7}{|c|}{0.98} & \\
\hline R Square & \multicolumn{7}{|c|}{0.96} & \\
\hline $\begin{array}{l}\text { Adjusted R } \\
\text { square }\left(\mathrm{R}^{2)}\right. \\
\end{array}$ & \multicolumn{7}{|c|}{0.95} & \\
\hline Standard Error & \multicolumn{7}{|c|}{4298457.57} & \\
\hline Observations & \multicolumn{7}{|c|}{20.00} & \\
\hline & & & ANOVA & & & & & \\
\hline & $d f$ & SS & $M S$ & $F$ & \multicolumn{2}{|c|}{ Significance $F$} & & \\
\hline Regression & 1 & $7.14009 \mathrm{E}+15$ & $7.14 \mathrm{E}+15$ & 386.4369 & 1.3E-13 & & & \\
\hline Residual & 18 & $3.32581 \mathrm{E}+14$ & $1.85 \mathrm{E}+13$ & & & & & \\
\hline \multirow[t]{2}{*}{ Total } & 19 & 7.47267E+15 & & & & & & \\
\hline & Coefficients & $\begin{array}{c}\text { Standard } \\
\text { Error }\end{array}$ & $t$ Stat & $P$-value & $\begin{array}{c}\text { Lower } \\
95 \% \\
\end{array}$ & $\begin{array}{c}\text { Upper } \\
95 \% \\
\end{array}$ & $\begin{array}{l}\text { Lower } \\
95.0 \% \\
\end{array}$ & $\begin{array}{l}\text { Upper } \\
95.0 \% \\
\end{array}$ \\
\hline Intercept & -6546638279 & 336792526.1 & -19.4382 & $1.57 \mathrm{E}-13$ & $-7 \mathrm{E}+09$ & $-5.8 E+09$ & $-7.3 \mathrm{E}+09$ & $-6 \mathrm{E}+09$ \\
\hline
\end{tabular}




\begin{tabular}{|c|c|c|c|c|c|c|c|c|}
\hline 2010 & 3276733.402 & 166687.0352 & 19.658 & $1.3 \mathrm{E}-13$ & 2926537 & 3626930 & 2926537 & 3626930 \\
\hline $\begin{array}{l}\text { RESIDUAL } \\
\text { OUTPUT }\end{array}$ & & & & \multicolumn{5}{|c|}{ PROBABILITY OUTPUT } \\
\hline Observation & $\begin{array}{l}\text { Predicted } \\
47880000\end{array}$ & Residuals & & Percentile & \multicolumn{4}{|c|}{$47,880,000$} \\
\hline 1 & 42872593.72 & $5,507,406.28$ & & 2.5 & \multicolumn{4}{|c|}{$48,380,000$} \\
\hline 2 & 46149327.12 & $3,048,395.15$ & & 7.5 & \multicolumn{4}{|c|}{$49,197,722$} \\
\hline 3 & 49426060.53 & $868,304.64$ & & 12.5 & \multicolumn{4}{|c|}{$50,294,365$} \\
\hline 4 & 52702793.93 & $-1,068,219.28$ & & 17.5 & \multicolumn{4}{|c|}{$51,634,575$} \\
\hline 5 & 55979527.33 & $-2,793,353.29$ & & 22.5 & \multicolumn{4}{|c|}{$53,186,174$} \\
\hline 6 & 59256260.73 & $-4,336,347.26$ & & 27.5 & \multicolumn{4}{|c|}{$54,919,913$} \\
\hline 7 & 62532994.14 & $-5,723,756.29$ & & 32.5 & \multicolumn{4}{|c|}{$56,809,238$} \\
\hline 8 & 65809727.54 & $-6,979,655.66$ & & 37.5 & \multicolumn{4}{|c|}{$58,830,072$} \\
\hline 9 & 69086460.94 & $-8,125,839.87$ & & 42.5 & \multicolumn{4}{|c|}{$60,960,621$} \\
\hline 10 & 72363194.34 & $6,232,010.50$ & & 47.5 & \multicolumn{4}{|c|}{$78,595,205$} \\
\hline 11 & 75639927.75 & $5,248,088.64$ & & 52.5 & \multicolumn{4}{|c|}{$80,888,016$} \\
\hline 12 & 78916661.15 & $4,320,408.27$ & & 57.5 & \multicolumn{4}{|c|}{$83,237,069$} \\
\hline 13 & 82193394.55 & $3,434,588.07$ & & 62.5 & \multicolumn{4}{|c|}{$85,627,983$} \\
\hline 14 & 85470127.95 & $2,577,734.18$ & & 67.5 & \multicolumn{4}{|c|}{$88,047,862$} \\
\hline 15 & 88746861.36 & $1,738,315.60$ & & 72.5 & \multicolumn{4}{|c|}{$90,485,177$} \\
\hline 16 & 92023594.76 & $906,048.94$ & & 77.5 & \multicolumn{4}{|c|}{$92,929,644$} \\
\hline 17 & 95300328.16 & $71,792.13$ & & 82.5 & \multicolumn{4}{|c|}{$95,372,120$} \\
\hline 18 & 98577061.56 & - 772,553.89 & & 87.5 & \multicolumn{4}{|c|}{$97,804,508$} \\
\hline 19 & 101853795 & $-1,634,135.72$ & & 92.5 & \multicolumn{4}{|c|}{$100,219,659$} \\
\hline 20 & 105130528.4 & $-2,519,231.12$ & & 97.5 & \multicolumn{4}{|c|}{$102,611,297$} \\
\hline
\end{tabular}

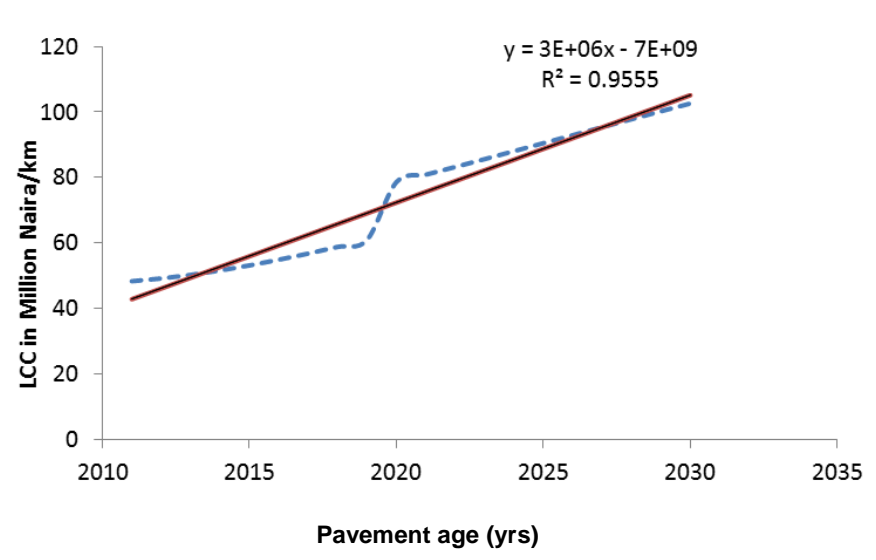

Fig. 5: Life Cycle Cost vs Pavement age plot for ICPB model

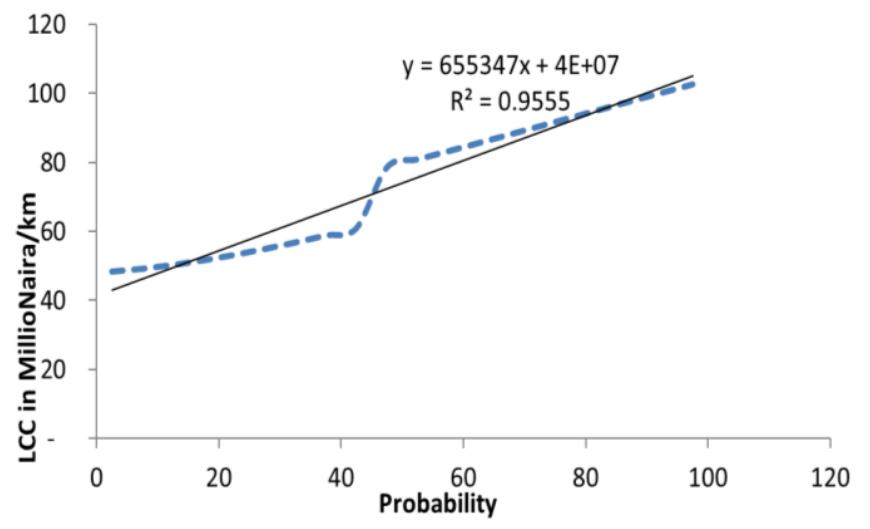

Fig. 6: Cycle Cost vs Probability plot for ICPB model

Table 4: Summary of the output of Life Cycle Cost for Do-Nothing Pavement model

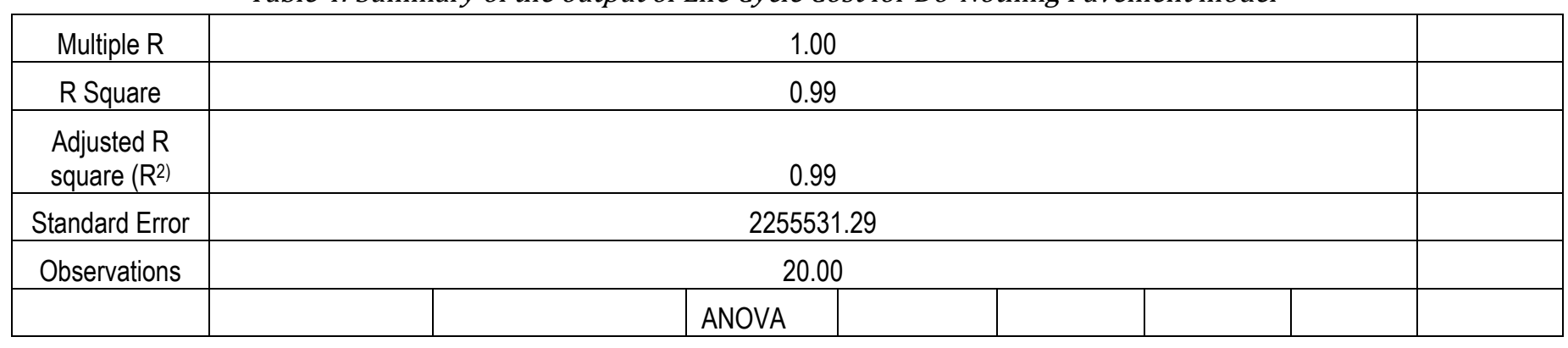




\begin{tabular}{|c|c|c|c|c|c|c|c|c|}
\hline & $d f$ & SS & MS & $F$ & \multicolumn{2}{|c|}{ Significance $F$} & & \\
\hline Regression & 1 & $1.282 \mathrm{E}+16$ & $1.3 E+16$ & 2519.9 & 8.4E-21 & & & \\
\hline Residual & 18 & $9.15736 \mathrm{E}+13$ & $5.1 \mathrm{E}+12$ & & & & & \\
\hline Total & 19 & $1.29115 \mathrm{E}+16$ & & & & & & \\
\hline & Coefficients & Standard Error & t Stat & P-value & $\begin{array}{l}\text { Lower } \\
95 \%\end{array}$ & $\begin{array}{l}\text { Upper } \\
95 \%\end{array}$ & $\begin{array}{l}\text { Lower } \\
95.0 \%\end{array}$ & $\begin{array}{l}\text { Upper } \\
95.0 \%\end{array}$ \\
\hline Intercept & -8834860757 & 176725271.2 & -49.9921 & 9E-21 & $-9.2 E+09$ & $-8 \mathrm{E}+09$ & $-9 \mathrm{E}+09$ & $-8.5 E+09$ \\
\hline \multirow[t]{2}{*}{2010} & 4390688.178 & 87465.75179 & 50.19894 & $8 \mathrm{E}-21$ & 4206929 & 4574447 & $4 \mathrm{E}+06$ & 4574447 \\
\hline & \multicolumn{2}{|l|}{ Residual output } & & & \multicolumn{2}{|c|}{ Probability output } & & \\
\hline Observation & Predicted 0 & Residuals & & Percentile & - & & & \\
\hline 1 & -5186830.279 & $5,586,830.28$ & & 2.5 & 400,000 & & & \\
\hline 2 & -796142.1004 & $2,167,497.04$ & & 7.5 & $1,371,355$ & & & \\
\hline 3 & 3594546.078 & - 748,556.44 & & 12.5 & $2,845,990$ & & & \\
\hline 4 & 7985234.256 & $-3,223,404.17$ & & 17.5 & $4,761,830$ & & & \\
\hline 5 & 12375922.43 & $1,648,447.57$ & & 22.5 & $14,024,370$ & & & \\
\hline 6 & 16766610.61 & $-108,515.09$ & & 27.5 & $16,658,096$ & & & \\
\hline 7 & 21157298.79 & $-1,579,004.82$ & & 32.5 & $19,578,294$ & & & \\
\hline 8 & 25547986.97 & - 2,805,446.89 & & 37.5 & $22,742,540$ & & & \\
\hline 9 & 29938675.15 & $-3,826,289.33$ & & 42.5 & $26,112,386$ & & & \\
\hline 10 & 34329363.33 & $477,311.97$ & & 47.5 & $34,806,675$ & & & \\
\hline 11 & 38720051.5 & - 233,341.57 & & 52.5 & $38,486,710$ & & & \\
\hline 12 & 43110739.68 & - 832,956.88 & & 57.5 & $42,277,783$ & & & \\
\hline 13 & 47501427.86 & $-1,347,041.41$ & & 62.5 & $46,154,386$ & & & \\
\hline 14 & 51892116.04 & $-1,798,502.84$ & & 67.5 & $50,093,613$ & & & \\
\hline 15 & 56282804.22 & $1,607,103.71$ & & 72.5 & $57,889,908$ & & & \\
\hline 16 & 60673492.39 & $1,221,498.17$ & & 77.5 & $61,894,991$ & & & \\
\hline 17 & 65064180.57 & $843,306.51$ & & 82.5 & $65,907,487$ & & & \\
\hline 18 & 69454868.75 & $458,012.65$ & & 87.5 & $69,912,881$ & & & \\
\hline 19 & 73845556.93 & $52,770.18$ & & 92.5 & $73,898,327$ & & & \\
\hline 20 & 78236245.11 & $2,440,281.36$ & & 97.5 & $80,676,526$ & & & \\
\hline
\end{tabular}

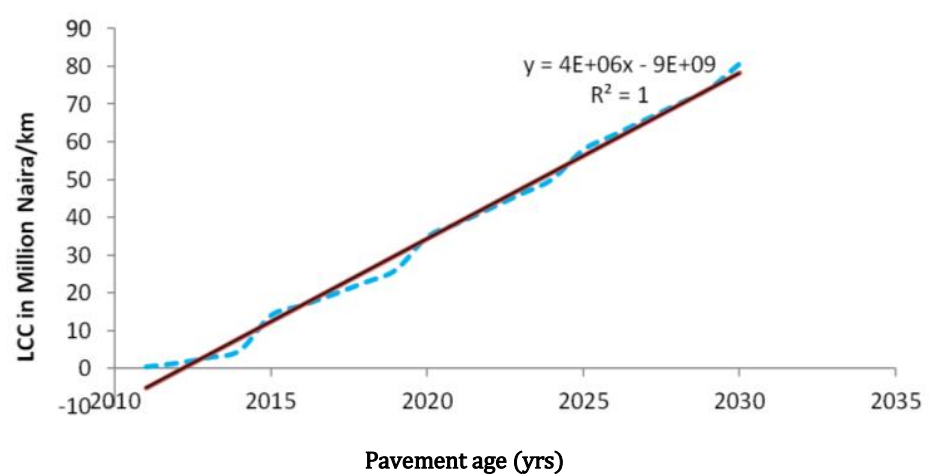

Fig. 7: $\quad$ Life Cycle Cost vs Pavement age plot for Do-Nothing model

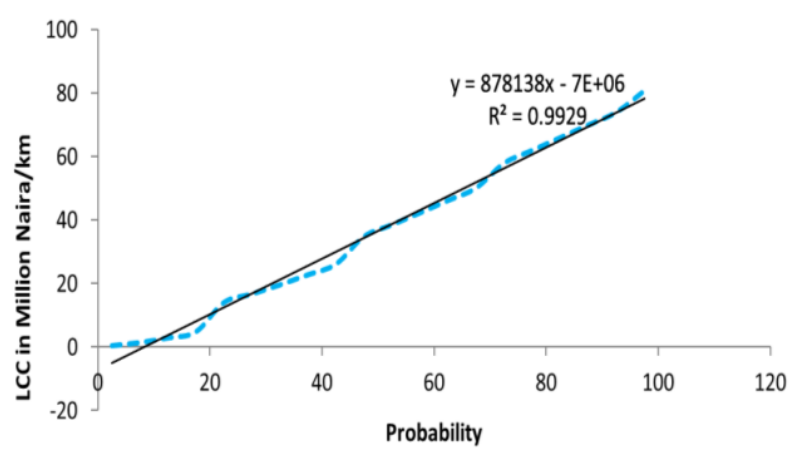

Fig. 8: Life Cycle Cost vs Probability plot for DoNothing model 


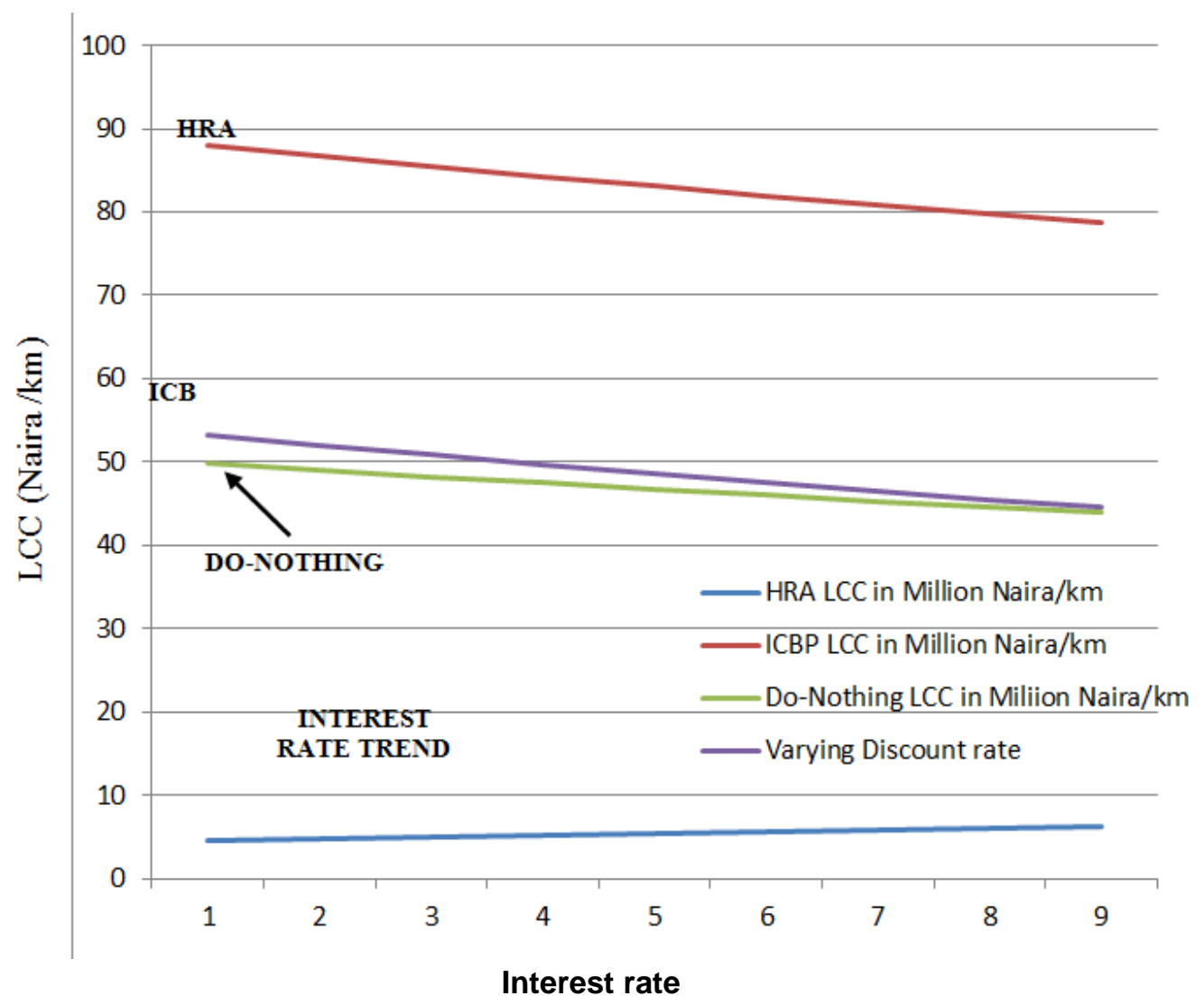

Fig. 9: Life Cycle Cost vs Interest Rate Sensitivity Graph for the three competing alternatives.

\section{DISCUSSIONS}

All the options considered in the sensitivity analysis in this study have the same baseline conditions and designed performance level of service (LOS). The values of coefficient of determination $\left(\mathrm{R}^{2}\right)$ for the Hot Rolled Asphalt (HRA), Interlocking Concrete Pavement Block (ICPB) and Do-nothing models (shown in Fig. 1) are 0.97, 0.95 and 0.99 respectively. These values are close to unity (one) which indicates a robustness of the models replicating the data used in the analysis.

The HRA and ICPB alternatives met the required level of services (LOS) while the Do-nothing scenario does not meet the level of service based on the reduced speed, poor driving characteristics, potholing and poor aesthetics observed in the Do-Nothing alternative that is without a binder or wearing surface course after the rainy season. The Do-Nothing alternative is therefore an unacceptable option.

The Sensitivity Analysis of the Life Cycle Cost for the alternatives presented in the interest rate sensitivity graph (Fig. 9) indicates a decrease with increasing interest rates for the three alternatives. The result also shows that the initial agency cost of the procurement of flexible pavement infrastructure and discount rate are significant parameters when an economic evaluation is done using the present worth cost method. The procedure and concept study are applicable in allied problem areas and sectors. The sensitivity analysis also indicates a decrease in life cycle cost (LCC) in Million Naira/Kilometer with increasing interest rate for the three alternatives.

As indicated in Tables 2-4, the significant value is much less than 0.05 rejection of a null hypothesis that $\mathrm{B}=0$ is adequately based on the assumption that the error term e (see equation 2) in the linear regression LCCA model is independent of $\mathrm{X}$ and normally represented with zero mean and constant variance. The models Independent variable (project age in years) can significantly predict the dependent variable (LCC) in Millions of Naira per kilometer.

It is observed that the results of the sensitivity analysis have no effect on the R-square values or Goodness of fit statistics. The goodness of fit of the developed economic models as observed from the Rsquare values which range from 0.95 to 0.99 shows robusity. The SPSS analysis has a Durbin-Watson statistic coefficient of 0.95 (shown in Fig. 2). This show that the LCC model is highly robust in replicating the project data used in the analysis.

Statistical parameters in Figs. 2-8 indicate that the cost models are between 0.950 - 0.999 with 
significance value of less than 0.001 . Statistically, the parameters obtained in this study are in conformity with the result of [29] in his study on "Cost Model for Pre-and Post-Haulage Road Freight Transport to and from the Intermodal Terminal" in Sweden, which had a mean square value $\left(\mathrm{R}^{2}\right)$ of 0.96 with a significance value of $(F)$ of 0.001 .

\section{CONCLUSION}

The study has shown that sensitivity analysis on the Life- Cycle Cost (LCC) model is necessary to achieve optimality and higher confidence level in model guided decision formulation especially for transport infrastructural delivery with high investment risk, challenges and funds.

Sensitivity analysis is often performed on developed Life-Cycle Cost Analysis (LCCA) models in line with available funds, available technology, construction supervisory experience, competency of contractors, interest rate, effective construction season etc. The sensitivity analysis of the life cycle cost in the study area has shown a decrease with increasing interest rates for the three alternatives.

\section{REFERENCES}

[1] Asta, G. "Life Cycle Cost Analysis of Asphalt and Concrete Pavements" Thesis submitted to the School of Science and Engineering at Reykjavík University in impartial fulfillment of the requirements for the degree of Master of Science, Iceland. 2011.

[2] Walls, J. I., \& Smith, M. "Life-Cycle Cost Analysis in Pavement Design" Interim Technical Bulletin. Washington, DC: Pavement Division, Office of Engineering -Federal Highway Administration. 1998.

[3] Keoleain, G. and Spitzley, D. "Sustainability Science and Engineering" The Netherlands: Elsevier. 2006.

[4] Huvstig, A. "Economic Models as Basis for Investment Decision." $10^{\text {th }}$ International Symposium on Concrete Roads, Turkey, Istanbul. 2004.

[5] Kai, G. "Developing Financial Decision Support for Highway Infrastructure Sustainability" PhD. Thesis, Queensland University of Technology. Australia. 2011

[6] Karim, H. "Improved Road Design for Future Maintenance - Analysis of Road Barrier Repair Costs" Licentiate Thesis, Royal Institute of Technology, Sweden, Stockholm. 2008.

[7] Mazen, F. and Tarek, Z. "Comparative Analysis of Life-Cycle Costing for Rehabilitating Infrastructure Systems". http://users.encs.concordia.ca/ zayed/ JOURNALS/13.pdf. 2009.
[8] Washington States Departmewnt of Transport (WSDOT). "Pavement Policy No. 42” USA. 2011.

[9] Jawad, D. "Life Cycle Cost Optimization for Infrastructure Facilities". PhD. Thesis, Rutgers, New Jersey State University, New Jersey. 2003

[10] Karen, R. Jennifer, E. and Madhav, P. "Training on Cost Estimation \& Analysis" National Research Council Canada (NRC-CNRC) Software Cost Estimation and Control" 1994.

[11] FHWA. "Life-Cycle Cost Analysis in Pavement Design-Search for Better Investment Decisions" Interim Technical Bulletin on LCCA, Washington, DC: United States Department of Transportation Federal Highway Administration. 1998.

[12] Haas, R., Hudson, W.R. and Zaniewski, J. "Modern Pavement Management" Krieger Publishing Company, Malabar, Florida. 1994.

[13] Adams, T. and Kang, M. "Considerations for Establishing Pavement Preservation Program" Transportation Research Board 85th Annual meeting, USA, Washington D.C. 2006.

[14] Stenbeck, T. "Incentives to Innovations in Road and Rail Maintenance" Licentiate Thesis, Royal institute of Technology, Sweden, Stockholm. 2004.

[15] Kato, H. Kitano, Y. and Hayashi, Y. "A Life Cycle estimation of various Environmental Loads in Urban Space Restructuring" http://www.fig.net/resources/ proceedings/fig proceedings/korea/full-papers/ session23/kitano-kato Japan. 2000.

[16] Borgonovo, E. and Peccati, L. "Sensitivity analysis in investment project evaluation" IMQ Universit'a "Bocconi" Viale Isonzo 25, Milan 20136, Italy.www.sciencedirect.com. 2003.

[17] Clemen, R., "Making Hard Decisions". Duxbury Press, Blement, CA. 1998.

[18] Borgonovo, E. and Apostolakis, E. "On local sensitivity measures". Proceedings of Sensitivity Analysis of Model Output, Madrid, 2001.

[19] Borgonovo, E. "Importance relations and sensitivity analysis in decision theory". Proceedings of the Tenth International Conference on Foundations and Applications of Utility, Risk and Decision Theory, Torino, 2001.

[20] Cheok, C., Parry, W. and Sherry, R.,. "Use of importance measures in risk-informed regulatory applications" Reliability Engineering and System Safety 60, 213-226. 1998.

[21] Helton, C. "Uncertainty and sensitivity analysis techniques for use in performance assessment for radioactive waste disposal" Reliability Engineering and System Safety 42, 327-367. 1993.

[22] Koltai, T. and Terlaky, T. "The difference between the managerial and mathematical interpretation of sensitivity analysis results in linear 
programming" International Journal of Production Economics 65 (3), 257-274. 2000.

[23] Ren, J., Manzardo, A., Zuliani, F., \& Scipioni, A. "Prioritization of Bioethanol Production pathways in China based on Life Cycle Sustainability assessment and Multicriteria decision making" The International Journal of Life Cycle Assessment, 1-12. 2015.

[24] Audu H., Aniekwu N. and Oghorodje E. "Life Cycle Cost Analysis (LCCA) Delivery Model for an Urban Flexible Pavement. Journal of Civil and Environmental Engineering Volume 5: 175. ". 2015.

[25] Morian, A., Zhao, Y., Arellano, J. and Hall, D., "Asphalt Pavement Rehabilitation Treatment" Analysis of 20 Years of Performance, Transportation Research Record 1905, Washington D.C. 2005.

[26] Nicholas, J. and Lester, A. Traffic and Highway Engineering for Undergraduate Studies in
Transportation, Highway and Traffic Engineering. $2^{\text {nd }}$ Edition (USA).1999.

[27] Kumares, C., Darcy, B., Chris, T., Herbert, S., Richard, W., Essam, R. and Zongzhi, L. "Development of Transportation Engineering Research, Education, and Practice in Changing Civil Engineering World" Journal of Transportation Engineering. www.cmu.edu/gdi/docs./development-of transportation, ASCE, USA. 2002.

[28] AASHTO. "AASHTO Guide for Design of Pavement Structures", American Association of State Highway and Transportation Officials. Washington, D.C.Vol.1, 44pp. 1993.

[29] Kazil, J. "Cost Model for Pre-and Post-Haulage Road Freight Transport to and from the Intermodal Terminal" in Sweden. www.script.org/journal/paper download. 2009. 